\section{Revista de la \\ Universidad del Thulia}

Fundada en 1947 por el Dr. Jesúns Enrique Lossada

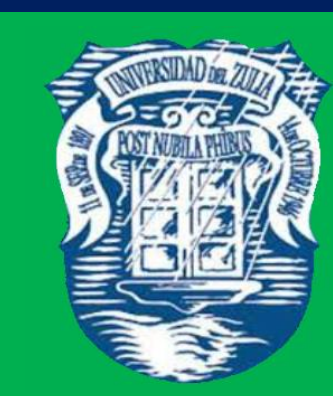

Ciencias del

Algreo

Ingemieria

y Teemología

\section{Aกัต 11 No 29}

Enero - Abril 2021

Tercera Época

Maracaibo-Venezuela 


\title{
Theoretical methods for measuring chemo-physical properties of nucleic acids during the oxidation of DNA and the incidence of cancer
}

\author{
Mehdi Imanzadeh * \\ Karim Zare* \\ Majid Monajjemi ${ }^{* *}$ \\ Ali Shamel ${ }^{* * *}$
}

The purpose of this papers is to investigate theoretical methods to measure the chemophysical properties of nucleic acids during DNA radicalization and cancer incidence. For this purpose, structures consisting of DNA nucleotides were considered and all structures were optimized using DFT at the CAM-B3LYP / 6-31G level and spatial parameters such as bond length, HOMO and LUMO orbitals, and thermodynamic parameters were obtained, as well as NMR spectroscopy. The results showed that the guanine base had better conditions for oxidation compared to other bases. Also in the NMR calculations using the GIAO method we were able to examine the single and double chain structure in different states when it is natural and abnormal. Therefore, in this work, we try to find a normal relationship between chemical displacement and the rate of natural state DNA aberration, by studying the comparison of isotropic and anisotropic parameters with respect to DNA bases such as adenine, guanine, cytosine, thymine. It was concluded that the skewness $(\eta)$ is between $(0.1)$ and the skewness is between (1-1), which can be correlated with the abnormalities of the DNA base from the normal to abnormal state. It was also found that the phosphate group oxygen atom in the abnormal form showed most of the changes in these parameters compared to the natural form.

KEYWORDS: Cancer, Mutation, Chemo-physical properties, Nucleic acid, DNA, NMR.

*Department of Chemistry, science and research branch, Islamic Azad University, Tehran, Iran.k-zare@srbiau.ac.ir

**Department of Chemical Engineering, Central Tehran branch, Islamic Azad University, Tehran, Iran.

***Department of Chemistry, Ardabil branch, Islamic Azad University, Ardabil, Iran. 
Métodos teóricos para medir las propiedades quimio-físicas de los ácidos nucleicos durante la oxidación del ADN y la incidencia de cáncer

\section{RESUMEN}

El propósito de este trabajo es investigar los métodos teóricos para medir las propiedades quimio-físicas de los ácidos nucleicos durante la radicalización del ADN y la incidencia de cáncer. Para este propósito, se consideraron las estructuras que consisten en nucleótidos de ADN y se optimizaron todas las estructuras utilizando DFT a nivel CAM-B3LYP / 6-31G y se obtuvieron parámetros espaciales tales como longitud de enlace, orbitales HOMO y LUMO y parámetros termodinámicos, así como espectroscopía de RMN. Los resultados mostraron que la base de guanina tenía mejores condiciones para la oxidación en comparación con otras bases. También en los cálculos de RMN utilizando el método GIAO pudimos examinar la estructura de cadena simple y doble en diferentes estados cuando es natural y anormal. Por lo tanto, en este trabajo, intentamos encontrar una relación normal entre el desplazamiento químico y la tasa de aberración del ADN del estado natural, mediante el estudio de la comparación de parámetros isotrópicos y anisotrópicos con respecto a bases de ADN como adenina, guanina, citosina, timina. Se concluyó que la asimetría ( $\eta$ ) está entre $(0,1)$ y la asimetría está entre (1-1), lo que puede correlacionarse con las anomalías de la base de ADN desde el estado normal a anormal. También se encontró que el átomo de oxígeno del grupo fosfato en la forma anormal mostró la mayoría de los cambios en estos parámetros en comparación con la forma natural.

PALABRAS CLAVE: Cáncer, mutación, propiedades quimio-físicas, Ácido nucleico, ADN, RMN.

Introduction

The importance of public health of society and attention to the health of the people causes a society to be healthy and progressive. Also with the fast improvement of genetic knowledge in recent years and the recognition of the role of nucleic acids and DNA in various diseases, and in particular the refractory disease of cancer has caused special attention to be paid to its various applications in various fields of sciences and 
REVISTA DE LA UNIVERSIDAD DEL ZULIA. 3a época. Año $11 \mathrm{~N}^{\circ}$ 29, 2020

Mehdi Imanzadeh et al./// Theoretical methods for measuring chemo-physical... 428-446

industry such as chemistry, biochemistry and medical, pharmaceutical industries and for the treatment of diseases.

In recent years, with the help of computers and quantum methods, the achievement of the physical, chemical parameters of nucleic acids has been made possible to radicalize DNA and has been caused to know more the complex behavior of this vital component of body of living organisms. Using chemical accounting methods and QM / MM method in this research, it has been tried to use this extraordinary possibility in addition to filling the existing voids of experiential and experimental methods with a better knowledge of changes in the physiochemical structure of DNA, especially in conditions of radicalized and mutation agents that this knowledge will make DNA changes in cancer disease recognized and will lead to the treatment of this disease. The idea can also be a new independent opinion in the field of medical sciences which can be the basis for many future researches and studies, as well as it can be a big step for advancing scientific knowledge of scientists and researchers in molecular cell biology, biochemistry, chemistry, medicine, physiology science researchers and all subfield of the sciences above.

In a healthy living, there is always a balance between the rate of cell division and the natural death of the cell. A natural cell may be changed to a cancerous cell without any clear reason, but in most cases, the changing is made due to repeated confrontation with carcinogenic substances such as alcohol and tobacco and free radicals. The apparent form and the cancerous cells function with the normal cells are significantly different. A mutation or alteration made occurs in DNA or a genetic material of the cell. DNA is responsible for controlling and preserving apparent form and function of the cell. When the DNA of a cell changes and becomes cancerous, that cell differs from healthy cells (Aghelan and Panjehpour, 2016) and does not do the other tasks on the normal cells of the body. The modified cell is detached from its nearby cells and does not know when its growth should finish and die. In other words, the modified cell does not follow the instructions and internal signals that control other cells and acts independently instead of coordinating with other cells. Researchers found in their studies that non-genetic imbalances of protein lead to out-of-control growth and cancer (Lari et al., 2016). 
REVISTA DE LA UNIVERSIDAD DEL ZULIA. 3a época. Año $11 \mathrm{~N}^{\circ}$ 29, 2020

Mehdi Imanzadeh et al./// Theoretical methods for measuring chemo-physical... 428-446

Researchers concluded that the two proteins Plcyl and Grb2 were in competition with the Akt for binding during pathway while performing laboratory studies on the mice. When the Plcyl protein binds to this pathway, it activates cell proliferation, and protein Grb2 controls the cell proliferation. For any reason, cells which include (instruction of mistake and error of messenger RNA of nucleic acids and DNA deficit of protein Grb2), normal growth of cell is out of control and resulting in a probability of cancer. In addition, the protein p53 also plays vital and important role in controlling and preventing the growth of cancer cells as an inhibitor of tumor and cancer. Mutation in the gene DNA causes a disorder in the formation or production of the protein, and in most types of cancers, mutation in the gene is obvious, and biological studies in computations method due to special attention paid to the gene in recent decades by biomedical methods that can be indicated in computations methods as a way to confront with the laboratory and research constraints in this field (Zhai et al., 2012).

There are various mutation factors in the environment that can cause mutation and various diseases in humans such as high energy radiation, chemicals and stress. According to new analysis in scientist studies, consuming tobacco can averagely make mutation in DNA of a lung cell and make 17 types of cancer. In theory, each DNA mutation can provide the potential needed for the progressive activation of cellular degeneration, and ultimately these changes will lead to cancer. The main role of types of DNA polymerase enzymes is genome proliferation. The task of these enzymes is very important and vital, as any factor which make a disorder for these enzymes damage people's health (Yan et al., 2002).

One of the cases that can be considered for identifying DNA damages is identifying probable DNA damages against the oxidizing agents, including oxidizing chemicals and various incidence rays. Which result in present base's oxidation in the DNA and in particular, the present guanine base in DNA sequencing, which will be oxidized easier than bases (Steenken and Jovanovic, 1997), and has less oxidation potential. DNA somewhat has ability to restore itself, but when the number of this (Sun et al., 2015) the property of charges transport in DNA, in addition to creating ideal properties to identify the DNA sequencing in electrical and electrochemical biosensors, 
REVISTA DE LA UNIVERSIDAD DEL ZULIA. $3^{a}$ época. Año $11 N^{\circ}$ 29, 2020

Mehdi Imanzadeh et al./// Theoretical methods for measuring chemo-physical... 428-446

facilitates the oxidation capability of its present bases, genetic mutation and disorder in genetic process (Hall and Barton, 1996). Two mechanisms of electron transport and transport of electron hole were suggested for charge transport and oxidation transport of organic bases in two-strand. In transporting electron hole, mechanism of DNA bases oxidation, particularly guanine base is desired, but in electron transport should consider the role of all bases in charge transporting. Among the present two-strand bases, guanine property for charge transporting is better than other bases, so that the percentage of base guanine present in two-strand, will have a direct effect on the charge transport property in two-strand (Prat et al., 1998), the tendency for electron absorbing in guanine, is lesser than other present two-strand bases, in the other hand oxidation potential, makes guanine more favorable than other bases (Hume et al., 2013).

\section{Literature Review}

Larry et al. (2017), in a research utilized computer computational methods and molecular modeling on achieving new anti-cancer drugs. Anti-cancer drugs from the factors of Cytotoxic, which is specifically destroys the DNA, by the help of computational methods affects the drugs for genetic and epigenetic disorders and more specifically tended to process of convert and development of malignant cells. Accessing to information of human genome and targeting vulnerable genes of cancer, by the use of computational modeling and prognosis, makes diagnosis and treatment of cancer possible with lesser cost and time. In recent years, the use of computational chemistry and molecular modeling for designing drug by the help of computer attracted pharmaceutical specialists. Initially, by computational modeling method the key factors that are not attainable through examination, computed by simplifying concept of cancer to the four level of atomic, molecular, microscopic, and macroscopic. The computational activity of the MTT assay showed that Atorvastatin, which is a cholesterol synthesis inhibiting, has a significant effect on inhibiting growth of HeLa's cancer cells. Molecular dynamic studies of anti-tumor activity on Nelfinavir anti-aids drug in inhibiting cellular kinase protein and inhibiting growth of cancer cell showed that, docking of Thalidomide derivatives in multiple Myeloma was evaluated and showed that, the Pomalidomide Derivate has greatest effect on inhibiting alpha-beta 
REVISTA DE LA UNIVERSIDAD DEL ZULIA. 3a época. Año $11 \mathrm{~N}^{\circ}$ 29, 2020

Mehdi Imanzadeh et al./// Theoretical methods for measuring chemo-physical... 428-446

Tubulin Mitosis and inhibiting proliferation of cell division. Computational studies of Hydralazine, which is antihypertensive drug, showed that this compound by DNA methylation and inhibiting proliferation of growing cells has anti-cancer effect.

Asadi et al. (2018), in a research examined effect of complex Manganese (II) andits bound to DNA and molecular docking by the use of DFT computational method and IR \& UV theory studies. In this research, the interaction amount of related complex of metallic center to DNA by the use of CD spectroscopy methods and UV-Vis spectroscopy method, Electrophoresis gel, viscosity and Cyclic voltammetry were studied. The interaction of this compound with two types of DNA in Leukemia indicates excellent interaction of this compound similar to Cisplatin anti-cancer drug. Then in the theory section, electron density theory was used to computation and optimization of geometry. Theoretical computations showed that, the complex interaction with the small DNA screws had a higher interaction.

Bandiopyas et al. (2016), in a research surveyed the link structure and molecular singularity between DNA and Ligands based on oxime and Palladium complexes by using DFT computational method. In this study, interaction of Palladium complex (II) with Phenyl (Pyridine-2- hydrazine) Acetaldehyde oxime (LH) and pair of twostranded base of DNA were studied by using DFT computational method. Spectral, electrochemical and biophysics behavior of this set were evaluated. In terms of physicochemical parameters, the following binding constants were resulted. For Ligand of binding constant $3.93 \times 10^{4}$ and for consonant complex $1.38 \times 10^{3} \mathrm{M}^{-1}$ were resulted.

Hume et al. (2013), in a research surveyed the formation of Mitomycin as an alkylating agent through DFT computational method. The mechanism of DNA complex formation with other complexes has been very successful with DFT computational method, particularly for simple models. By comparing obtained results of computations, mechanical properties were predicted with high accuracy. Reduction of one and two-electron of system strongly depends on ph.

The property of charge transfer in the DNA, not only creates ideal properties to detect the sequence of DNA in the electrical and electrochemical biosensors, but also 
facilitates the oxidation capability of bases existing in it and also leads to genetic mutation and disorder in the genetic process (Gray, 2006).

Two mechanisms of the electron transfer and electron hole are recommended for transferring of charge and oxidation of organic bases in two strands. In transmitting the electron hole, the oxidation mechanism of the DNA, especially the base of the guanine, is intended; but in the transmission of electron, the role of transferring the charge of all the bases should be considered. Among the bases existing in double strands, the property of guanine charge transfer is better than other bases; so that the percent of guanine base existing in the double strands have a direct effect on the property of charge transfer in the double strands (Forshew et al., 2012). The tendency for electron absorption in the guanine is less than other bases existing in the double strands. On the other hand, it makes the potential of guanine oxidation more susceptible than other bases (Bensimon et al., 2011).

\section{Computaional methods}

The molecular structure, quantum mechanics and Theoretical computations, charges distribution for RNA and DNA calculated using standard GIAO and B3LYP level of theory with 6-31 G(d) basis set with the gaussian 09 program to performed to study chemical and physical properties of nuclei and NMR chemical shift data [15] Gaussian 09 is a computational chemistry software package appropriate to demonstration interaction of electrons in atoms and molecules. Molecular orbital energies, bond energies, molecular geometries and energies, and vibrational frequencies are the other features can be found in this program. The chemical shift refers to aspect dependent on the secondary magnetic field created by the induced motions of the electrons surrounding nucleus $[16]$. The NMR analysis have been fulfilled with four

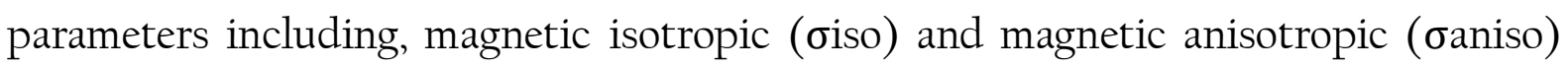
shielding, $\sigma_{11}, \sigma_{22}, \sigma_{33}$ as shown in the following result for its fundamental importance in chemistry and biochemistry studies, in which the $\sigma$ defined as magnetic shielding tensor(ppm) and $(\eta)$ defined as shielding asymmetry.$\sigma$ also refers to the differential resonance shift due to the induced motion of the electrons [17] . Kinetic and thermodynamic investigations, geometry optimization, Monte Carlo and vibrational 
REVISTA DE LA UNIVERSIDAD DEL ZULIA. 3a época. Año $11 \mathrm{~N}^{\circ}$ 29, 2020

Mehdi Imanzadeh et al./// Theoretical methods for measuring chemo-physical... 428-446

analysis done by using HyperChem 8.0.8 software which is a sophisticated molecular modeling environment that is familiar for its quality, Flexibility, and ease of use. 3D embodiment with quantum calculations, molecular mechanics, and dynamics are other capability of this tool ${ }_{[18]}$. For Mont Carlo in molecular mechanic method we optimized Potential, kinetic and total energy with 10 steps in $310 \mathrm{k}$ degree (the most stable and important temperature) and $298 \mathrm{k}$ degree (environment temperature) and for Semi empirical the Aml method with all parameters (Total Energy, Binding Energy, Isolated Atomic Energy, Electronic Energy, Core-Core Interaction and Heat of Formation) is the best vibration analysis of molecules using a quantum mechanical approach that was obtained Semi empirical (Mollaamin and Monajjemi, 2015).

\section{Results and Discussion}

3.1. Examination of Double-stranded NBO with sequences of AAAAA, GACTG and GGGGG

The energy levels and orbital shape of HOMO and LUMO from Gaussian Software and DFT calculations of this sequence are presented further. Table 1 presents the energy values of the single-stranded molecule with sequences of AAAAA, GACTG and GGGGG. The energy of formation for these sequences is also given in Table 2.

Table 1: HOMO and LUMO Energy in different double-strands

\begin{tabular}{lcc}
\hline Structure & HOMO(ev) & LUMO(ev) \\
\hline double-strand GGGGG & -0.30895 & -0.30401 \\
double-strand AAAAA & -0.31190 & -0.31093 \\
double-strand GACTG & -0.31037 & -0.30931 \\
\hline
\end{tabular}

Table 2: The formation energy in different double-standard

\begin{tabular}{lll}
\hline Structure & $\begin{array}{l}\text { HF of formation } \\
\text { energy (Hartree- } \\
\text { Fock) }\end{array}$ \\
\hline
\end{tabular}


REVISTA DE LA UNIVERSIDAD DEL ZULIA. 3a época. Año $11 \mathrm{~N}^{\circ}$ 29, 2020

Mehdi Imanzadeh et al./// Theoretical methods for measuring chemo-physical... 428-446

\begin{tabular}{lcc}
\hline GGGGG double-strand & 299.80268 & C01 \\
AAAAA double-strand & 2449.25418 & C01 \\
GACTG double-strand & 2756.235487 & C01 \\
\hline
\end{tabular}

\subsection{LUMO orbital}

The orbital shape of double-stranded HOMO with the GGGGG sequence is presented in the following figure. Due to the resonance of $\pi$-bond in natural molecular orbital structure, this molecule is very large and uninterrupted.
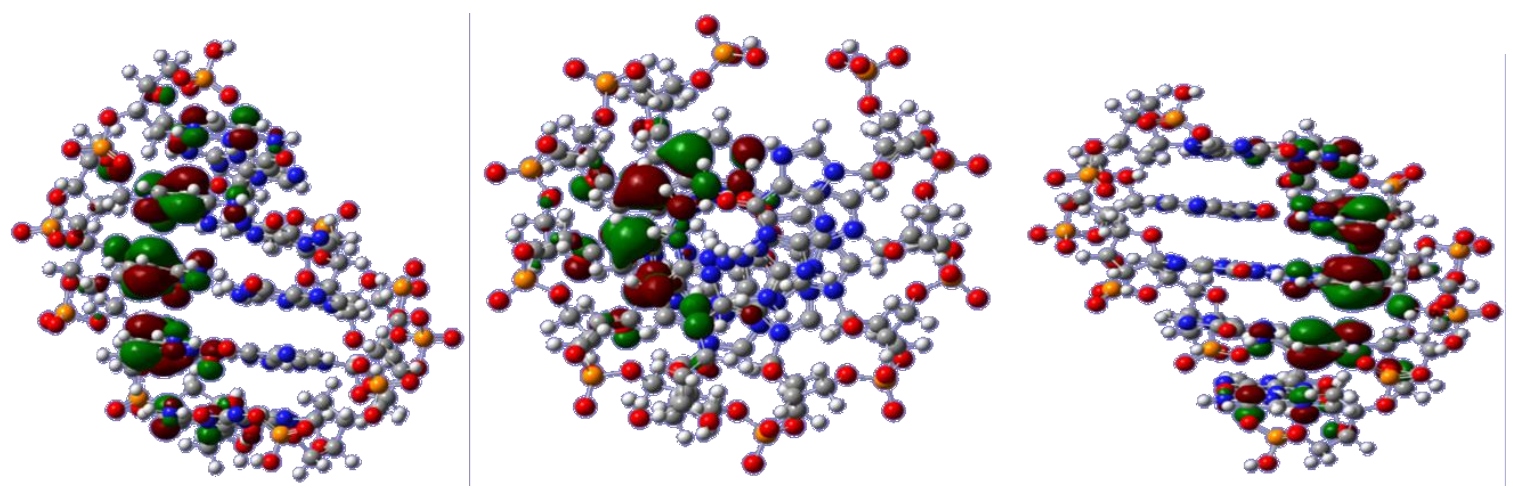

Fig l: LUMO orbital with GGGGG sequence

\subsection{HOMO orbital}

The orbital shape of double-stranded HOMO with the AAAAA sequence is presented in the following figure. 
REVISTA DE LA UNIVERSIDAD DEL ZULIA. $3^{a}$ época. Año $11 N^{\circ}$ 29, 2020

Mehdi Imanzadeh et al./// Theoretical methods for measuring chemo-physical... 428-446
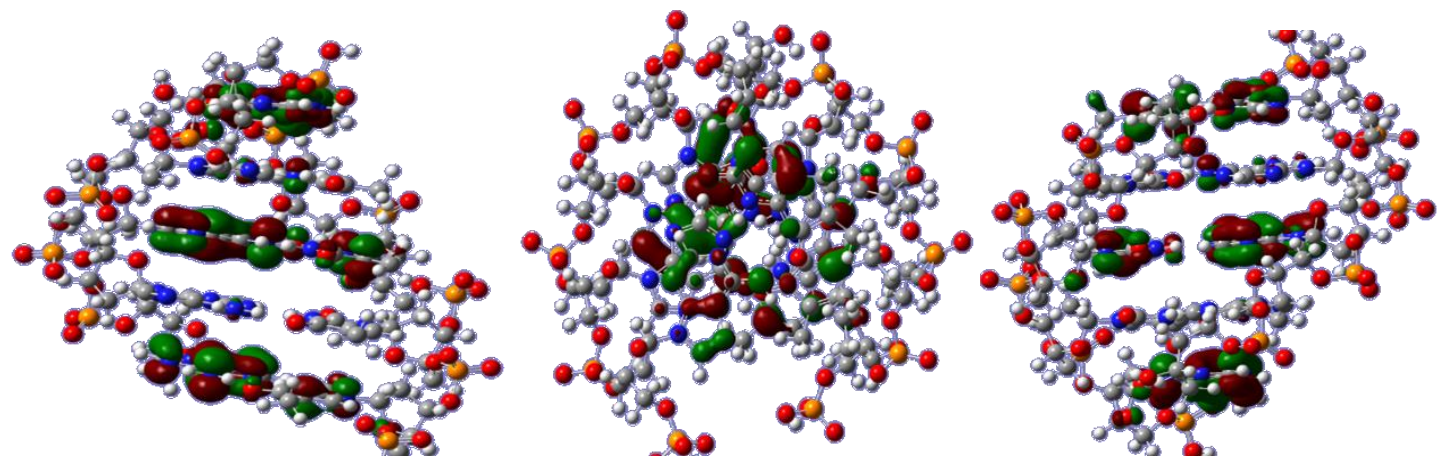

Fig 2: HOMO orbital with AAAAA sequence

Due to the calculations and also examination of the structure and arrangement of the LUMO and HOMO orbitals, it was found that the sequences with the largest number of guanine base are oxidized earlier and the charge transfer and oxidation process performed easier.

3.4. Investigation of isotropic and anisotropic parameters for bases and nucleotides.

According to the data and NMR calculations for isotropic and anisotropic parameters for the bases and nucleotides, a comparison was performed between the oxidized and normal states. In bases, according to data comparison, it was found that the highest difference between the oxidized and the normal state for the adenine, guanine, cytosine and thymine bases is in the $\mathrm{N}_{3}, \mathrm{~N}_{3}, \mathrm{~N}_{1}, \mathrm{~N}_{10}$ atoms, respectively, that is corresponding to the experimental results.

In nucleotides, according to data comparison, it was found that for isotropic and anisotropic parameters, the highest difference between the normal and oxidized state for adenosine, guanosine, cytidine, and thymidine in $\mathrm{O}_{2}$ atoms related to the phosphate group, that is corresponding to the experimental results.

3.5. Investigation of isotropic and anisotropic parameters for single-stranded and double-stranded DNA

The purpose of this project is to investigate the theoretical methods for measuring chemo-physical properties of nucleic acids during the radicalization of DNA and the incidence of cancer. For this purpose, structures consisting of DNA nucleotides were considered and all structures were optimized using DFT at CAM-B3LYP / 6-31G 
REVISTA DE LA UNIVERSIDAD DEL ZULIA. 3a época. Año $11 \mathrm{~N}^{\circ}$ 29, 2020

Mehdi Imanzadeh et al./// Theoretical methods for measuring chemo-physical... 428-446

level and spatial parameters such as bond length, HOMO and LUMO orbitals and thermodynamic parameters as well as NMR spectroscopy were obtained. The results showed that guanine base had better conditions for oxidation compared to other bases. Also in NMR calculations using the GIAO method we were able to examine the singlestrand and double-strand structure in different states of thesis when natural and abnormal.

Therefore, in this thesis, we attempted to find an normal relationship between chemical displacement and the rate of aberration of DNA from the natural state, by studying the comparison of isotropic and anisotropic parameters with respect to DNA bases such as adenine, guanine, cytosine, thymine, and concluded that asymmetry ( $\eta$ ) is between $(0,1)$ and skew is between (1-1) which can be correlated to the abnormalities of the DNA base from the normal state to abnormal.

It was also found that the oxygen atom of the phosphate group in the abnormal form showed the most changes in these parameters compared to the natural form. Also it can be seen by examining the chemical displacement spectra and anisotropy of the latency tensor in the Double-stranded DNA with GC sequence, the oxygen atom of the phosphate group in the guanosine nucleotide of the abnormal form has the highest value than the natural form and oxygen atoms belonging to the phosphate group in the cytotine nucleotide changed with less intense than guanine in these parameters. Also it can be seen by examining the spectra of Double-stranded DNA with AT sequence that the oxygen atom of the phosphate group in the abnormal form of the adenine nucleotide has the highest value than the natural form of DNA. Also the oxygen atom of the phosphate group in the thymidine nucleotide changed with less intense than adenine in these parameters, as shown in Fig 3 and 4. NMR calculations are also performed using the relations of 4-1 and 4-3.

$$
\begin{aligned}
& \Omega=\sigma_{33}-\sigma_{11} \\
& \kappa=\frac{3\left(\sigma_{i s 0}-\sigma_{22}\right)}{\Omega}
\end{aligned}
$$


REVISTA DE LA UNIVERSIDAD DEL ZULIA. 3ª época. Año 11 N² 29, 2020 Mehdi Imanzadeh et al./// Theoretical methods for measuring chemo-physical... 428-446

$$
\begin{aligned}
& \Delta \sigma=\sigma_{11}-\frac{\sigma_{22}+\sigma_{33}}{2} \\
& \eta=\frac{\sigma_{22}-\sigma_{33}}{\delta} \\
& 0^{\text {I20 }}=\frac{3}{\text { म.Sc6Q }}=\frac{3}{0^{I J}+0^{S S}+0^{33}}
\end{aligned}
$$

\begin{tabular}{|c|c|c|c|c|c|c|c|c|}
\hline $\begin{array}{l}\text { Atom } \\
\text { s } \\
\text { type }\end{array}$ & $\begin{array}{c}\boldsymbol{\sigma} \text { aniso } \\
\text { ppm }\end{array}$ & $\begin{array}{l}\boldsymbol{\sigma} \text { iso } \\
\text { ppm }\end{array}$ & $\begin{array}{c}\mathrm{K} \\
\mathrm{rad}\end{array}$ & $\begin{array}{c}\mathbf{\Omega} \\
\mathrm{ppm}\end{array}$ & $\begin{array}{c}\boldsymbol{\sigma} 33 \\
\text { ppm }\end{array}$ & $\begin{array}{c}\sigma 22 \\
\text { Ppm }\end{array}$ & $\begin{array}{c}\boldsymbol{\sigma} \text { oll } \\
\text { ppm }\end{array}$ & $\begin{array}{c}\text { Muliken } \\
\text { atomic } \\
\text { charge }\end{array}$ \\
\hline $\mathrm{O}$ & 137.0079 & 218.6819 & 0.091 & 69.8588 & 152.4007 & 281.3853 & $\begin{array}{c}222.259 \\
5\end{array}$ & -0.647948 \\
\hline $\mathrm{p}$ & $\begin{array}{c}258.044 \\
5\end{array}$ & 335.1564 & -0.021 & $\begin{array}{c}224.789 \\
4\end{array}$ & $\begin{array}{c}254.845 \\
5\end{array}$ & $\begin{array}{c}270.989 \\
0\end{array}$ & $\begin{array}{c}479.634 \\
9\end{array}$ & 1.495780 \\
\hline $\mathrm{O}$ & 961.7359 & 66.3624 & 0.013 & $\begin{array}{c}695.946 \\
5\end{array}$ & 440.8199 & 13.3940 & 255.1266 & $\begin{array}{c}0.5930299 \\
-\end{array}$ \\
\hline $\mathrm{O}$ & 6166.7607 & $\begin{array}{c}- \\
3973.440 \\
8\end{array}$ & 0.043 & $\begin{array}{c}6865.755 \\
2\end{array}$ & -8554.032 & -1678.0117 & 1688.2777 & -0.335427 \\
\hline $\mathrm{O}$ & 231.2869 & 268.2188 & -0.132 & 85.7005 & 274.7038 & 169.5483 & $\begin{array}{c}360.404 \\
3 \\
\end{array}$ & -0.613474 \\
\hline C & 34.4208 & 142.1014 & $\begin{array}{c}0.097 \\
-\end{array}$ & 13.2991 & 144.5186 & 150.5660 & 131.2195 & -0.160717 \\
\hline $\mathrm{N}$ & 68.5388 & 189.4703 & 0.069 & 33.9149 & 192.8832 & 216.5594 & .158 .968 & -0.706129 \\
\hline $\mathrm{N}$ & 380.1567 & 31.8259 & 0.069 & 427.6186 & 285.0197 & -46.9430 & 142.5989 & -0.574808 \\
\hline C & 121.3123 & 67.2695 & 0.036 & 143.4229 & 147.8067 & 49.6178 & 4.3838 & 0.639564 \\
\hline
\end{tabular}

Table 3: The values of adenosine nucleotide overlay parameters

Table 4. The values of adenosine oxide nucleotide overlay parameters

\begin{tabular}{ccccccccc}
\hline $\begin{array}{c}\text { Atom's } \\
\text { Type }\end{array}$ & $\begin{array}{c}\boldsymbol{\sigma} \text { aniso } \\
\text { ppm }\end{array}$ & $\begin{array}{c}\boldsymbol{\sigma} \text { iso } \\
\text { ppm }\end{array}$ & $\begin{array}{c}\mathrm{K} \\
\mathrm{ppm}\end{array}$ & $\begin{array}{c}\mathbf{\Omega} \\
\mathrm{ppm}\end{array}$ & $\begin{array}{c}\boldsymbol{\sigma} 33 \\
\mathrm{Ppm}\end{array}$ & $\begin{array}{c}\boldsymbol{\sigma} 22 \\
\text { Ppm }\end{array}$ & $\begin{array}{c}\boldsymbol{\sigma} \text { (l } \\
\text { ppm }\end{array}$ & $\begin{array}{c}\text { Muliken } \\
\text { atomic } \\
\text { charge }\end{array}$ \\
\hline $\mathrm{O}$ & 164.6387 & 199.2350 & 0.0952 & 42.9872 & 200.5285 & 153.6607 & 243.5157 & -0.6410 \\
\hline $\mathrm{P}$ & 326.7443 & 399.1740 & 0.054 & 185.1866 & 349.9045 & 312.5155 & 535.0911 & 1.6368 \\
\hline $\mathrm{O}$ & 202.1424 & 107.6228 & 0.033 & 181.2749 & 10.0672 & 121.4590 & 191.3421 & -0.3178 \\
\hline $\mathrm{O}$ & 188.7454 & 136.1039 & -0.045 & 42.8396 & 119.3799 & 126.7124 & 162.2195 & -0.3400 \\
\hline $\mathrm{O}$ & 185.1566 & 249.3519 & -0.053 & 70.9462 & 244.1889 & 188.7317 & 315.1351 & -0.5626 \\
\hline $\mathrm{C}$ & 54.7438 & 144.1590 & 0.014 & 22.0528 & 155.3159 & 143.8738 & 133.2631 & -0.1979 \\
\hline $\mathrm{N}$ & 59.1531 & 181.3394 & -0.432 & 18.7078 & 192.0187 & 141.2731 & 210.7265 & -0.7618 \\
\hline $\mathrm{N}$ & 241.7861 & 95.3768 & 0.011 & 174.9972 & 202.6740 & 55.7796 & 27.6768 & -0.7750 \\
\hline $\mathrm{C}$ & 122.4604 & 71.3949 & 0014 & 72.1281 & 113.8931 & 58.5268 & 41.7650 & 0.7061 \\
\hline
\end{tabular}


REVISTA DE LA UNIVERSIDAD DEL ZULIA. $3^{a}$ época. Año $11 N^{\circ}$ 29, 2020

Mehdi Imanzadeh et al./// Theoretical methods for measuring chemo-physical... 428-446
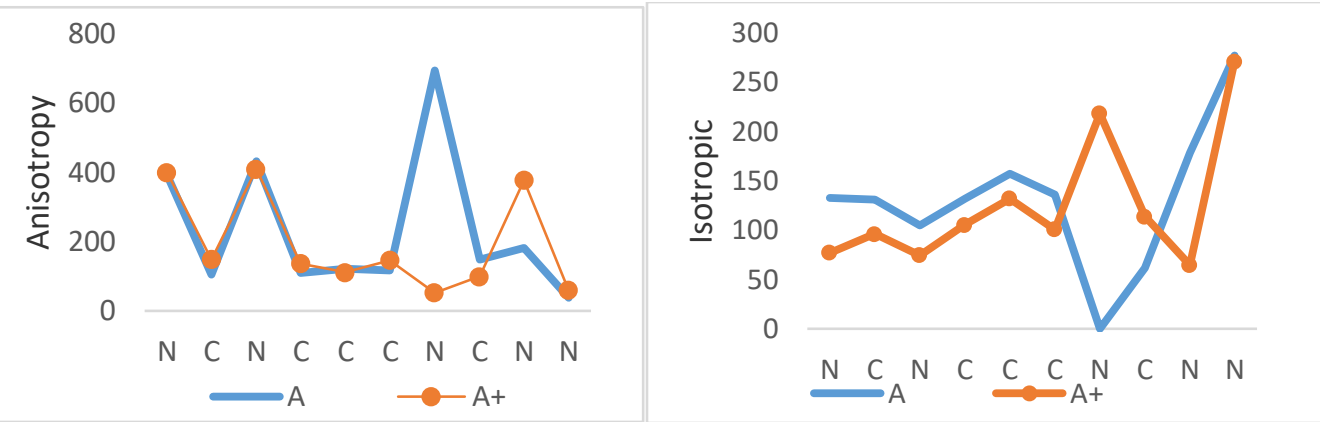

A)
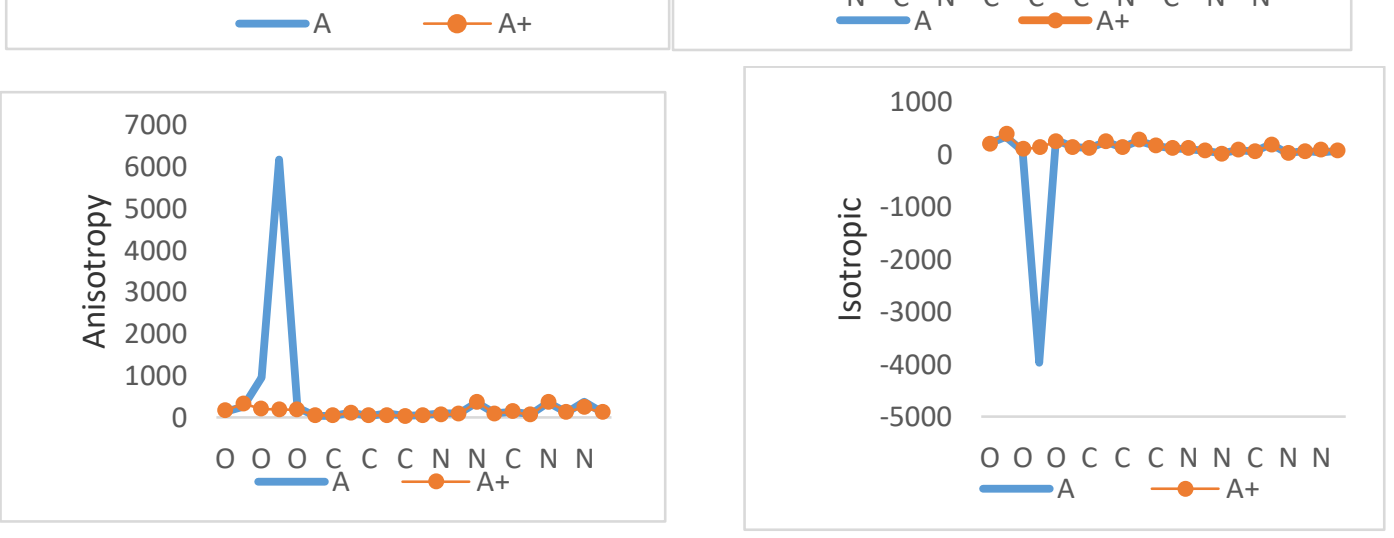

B)
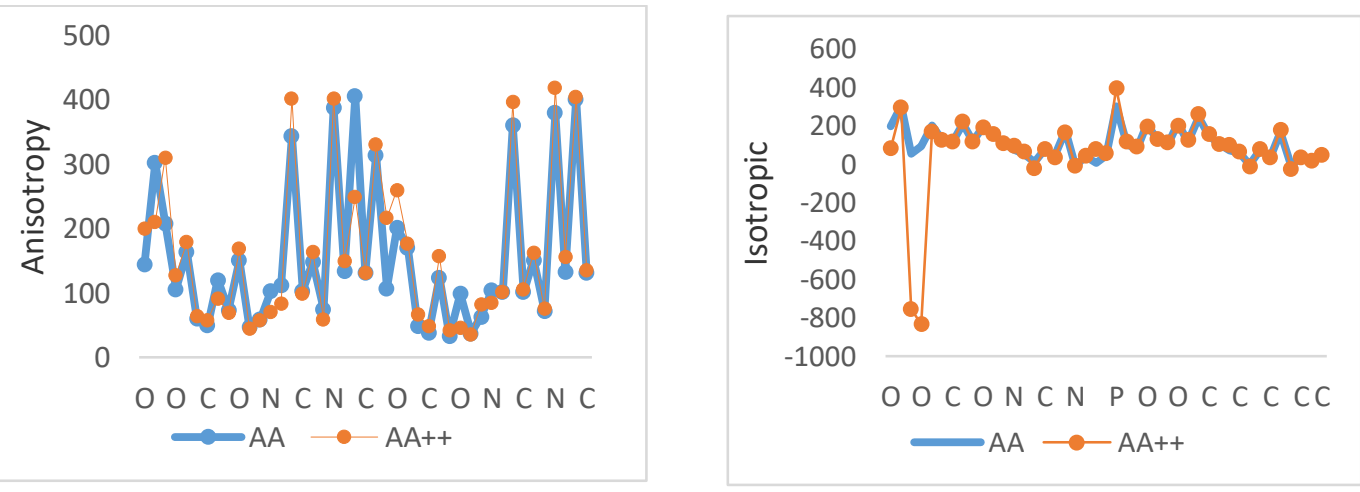

Fig 3: Charts Isotropic and Anisotropy A) Adenine B) Adenosine C) Single-strand and Oxidation form

Also it can be seen by examining the chemical displacement spectra and anisotropy of the latency tensor in the Double-stranded DNA with GC sequence, the oxygen atom of the phosphate group in the guanosine nucleotide of the abnormal form has the highest value than the natural form and oxygen atoms belonging to the phosphate group in the cytotine nucleotide changed with less intense than guanine in these parameters. Also it can be seen by examining the spectra of Double-stranded DNA with AT sequence that the oxygen atom of the phosphate group in the abnormal form of the adenine nucleotide has the highest value than the natural form of DNA. Also 
REVISTA DE LA UNIVERSIDAD DEL ZULIA. 3a época. Año $11 \mathrm{~N}^{\circ}$ 29, 2020

Mehdi Imanzadeh et al./// Theoretical methods for measuring chemo-physical... 428-446

the oxygen atom of the phosphate group in the thymidine nucleotide changed with less intense than adenine in these parameters.
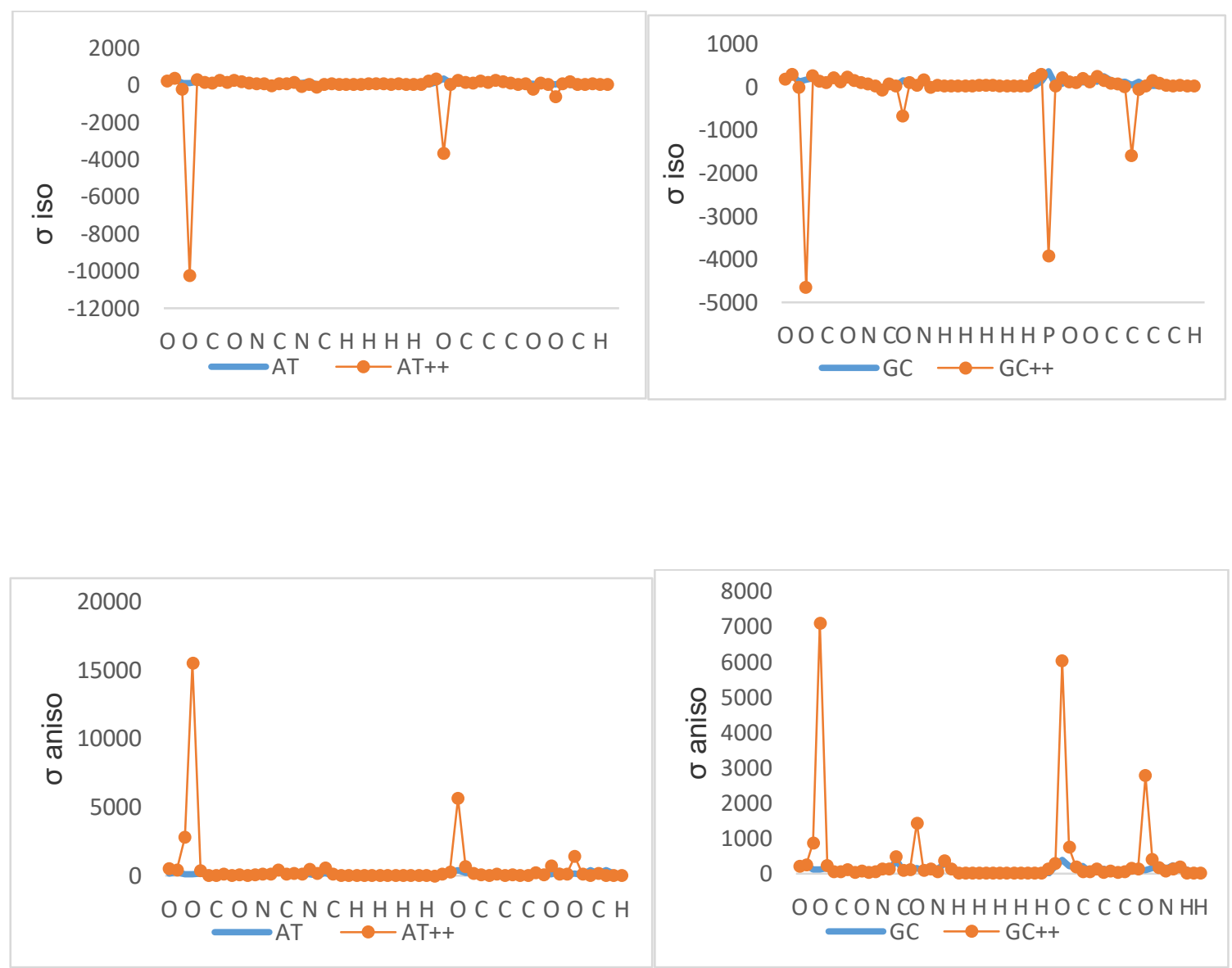

Fig 4: Isotropic and Anisotropy graphs of GC and AT Sequence and their doublestranded oxide form

3.6. Comparison of the anisotropy parameter of the latency tensor for DNA nucleotides

By examining the anisotropy parameter of the nucleotide lattency tensor, it was found that phosphate group oxygen has major changes in the natural and abnormal state that these parameters describe sample width and shape and with this a comparison can be made between the two states that shown in Fig 5. 
REVISTA DE LA UNIVERSIDAD DEL ZULIA. 3ª época. Año 11 N² 29, 2020

Mehdi Imanzadeh et al./// Theoretical methods for measuring chemo-physical... 428-446
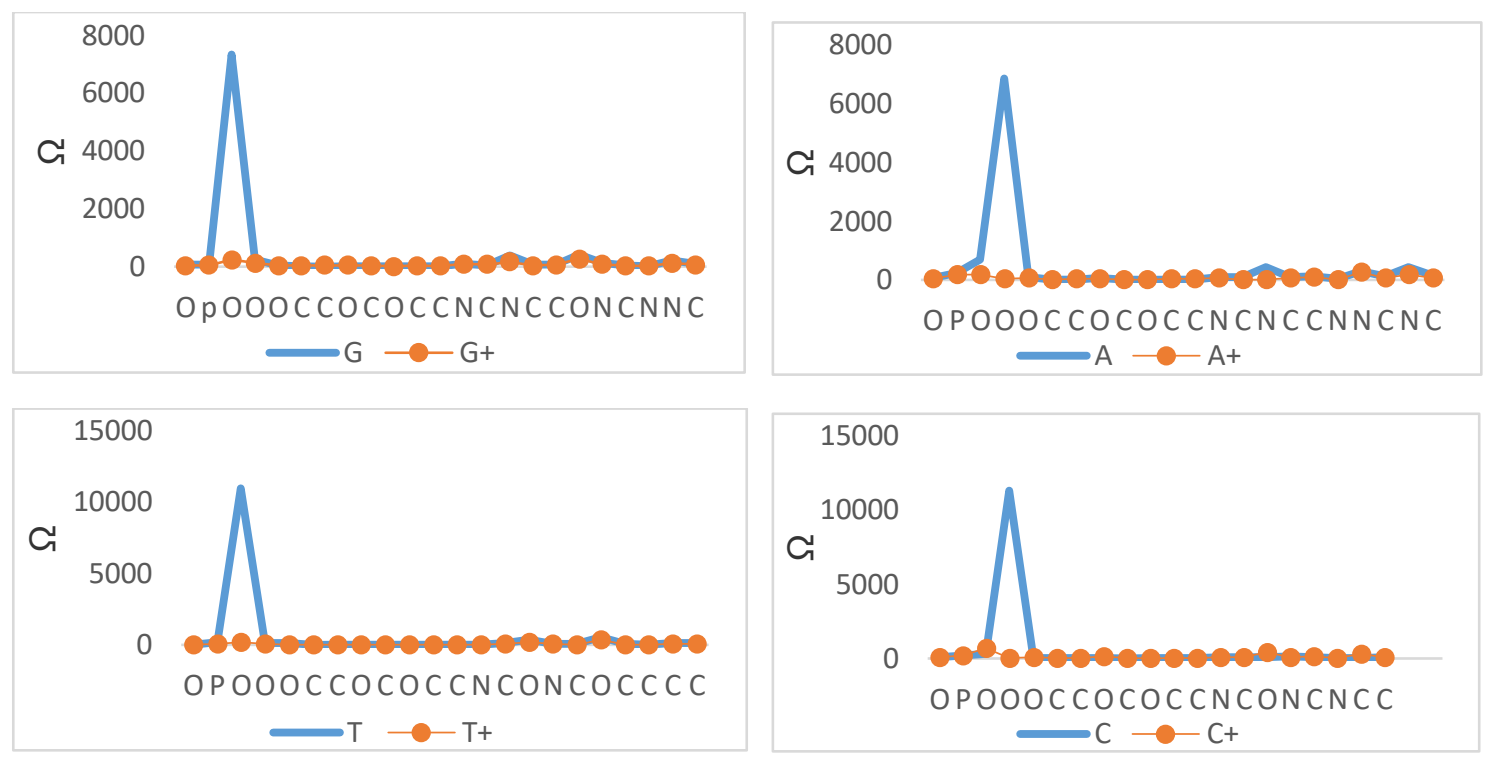

Figure 5: Comparision of Overaly Parameters for Nucleotide

\subsection{Investigation of Thermodynamic Parameters of DNA Nucleotides}

By studying the thermodynamic parameters much information can be obtained about how chemical reactions proceed and progress. In the present study, using the B3LYP / 6-31G FREQ order, we obtained thermodynamic parameters for DNA nucleotides, the values of which are reported in tables 5 to 7 . Thermodynamic properties including internal energy, enthalpy change, entropy change, Gibbs free energy change and specific heat capacity change were calculated for all DNA bases in different states at a temperature of 298.15. Initially, the values of the thermodynamic parameters were calculated using the relations 4-6 to 4-8, that results presented in tables 5 to 7 .

$$
\begin{aligned}
& \Delta \mathrm{H}(298 \mathrm{~K})=\Sigma \Delta \mathrm{H}_{\text {prod }}(298 \mathrm{~K})-\Sigma \Delta \mathrm{H}_{\text {reac }}(298 \mathrm{~K}) \\
& \Delta \mathrm{G}(298 \mathrm{~K})=\Sigma \Delta \mathrm{G}_{\text {prod }}(298 \mathrm{~K})-\Sigma \Delta \mathrm{G}_{\text {reac }}(298 \mathrm{~K}) \\
& \Delta \mathrm{G}=\Delta \mathrm{H}-\mathrm{T} \Delta \mathrm{S}
\end{aligned}
$$

In evaluating DNA bases observed that Guanine base compared to other bases has less $\Delta \mathrm{H}$ and less $\Delta \mathrm{G}$ as well as higher $\Delta \mathrm{S}$ than other bases, indicating that the guanine base is oxidized more readily than other bases and its irregularity increases. In evaluating DNA nucleotides observed that guanosine nucleotide compared to other nucleotides has less $\Delta \mathrm{H}$ and less $\Delta \mathrm{G}$ than other bases, indicating that guanosine 
REVISTA DE LA UNIVERSIDAD DEL ZULIA. $3^{a}$ época. Año $11 N^{\circ}$ 29, 2020 Mehdi Imanzadeh et al./// Theoretical methods for measuring chemo-physical... 428-446 nucleotide is relatively oxidized more easily than other bases and its irregularity increases.

In evaluating single-stranded DNA observed that the guanine-guanine base pair has less $\Delta \mathrm{H}$ and less $\Delta \mathrm{G}$ as well as higher $\Delta S$ than the other bases, indicating that guanosine nucleotide is relatively oxidized more easily than other bases and its irregularity increases.

Table 5: Difference of Thermodynamic Functions of DNA Bases and their oxide form

\begin{tabular}{cccccc}
\hline structure & $\begin{array}{c}\Delta \mathrm{E} \\
\mathrm{Kcal} / \mathrm{mol}\end{array}$ & $\begin{array}{c}\Delta \mathrm{CV} \\
\mathrm{Cal} / \mathrm{mol}- \\
\text { kelvin }\end{array}$ & $\begin{array}{c}\Delta \mathrm{S} \\
\mathrm{Cal} / \mathrm{mol}- \\
\text { kelvin }\end{array}$ & $\begin{array}{c}\Delta \mathrm{H} \\
\mathrm{Cal} / \mathrm{mol}- \\
\mathrm{kelvin}\end{array}$ & $\begin{array}{c}\Delta \mathrm{G} \\
\mathrm{Kcal} / \mathrm{mol}\end{array}$ \\
\hline Adenine & -3.854 & -1.676 & -0.0006 & 96.7619 & 96.9502 \\
Guanin & -3.77 & -0.265 & 0.0018 & 92.8714 & 92.3066 \\
Cytozin & -3.016 & -0.73 & -0.001 & 99.3347 & 99.6485 \\
Thymin & -5.838 & -3.148 & -0.009 & 109.1239 & 111.8221
\end{tabular}

Table 6: Difference of Thermodynamic Functions of DNA Nucleotides and their oxide for

\begin{tabular}{|c|c|c|c|c|c|}
\hline structure & $\begin{array}{c}\Delta \mathrm{E} \\
\mathrm{Kcal} / \mathrm{mol}\end{array}$ & $\begin{array}{c}\Delta \mathrm{CV} \\
\mathrm{Cal} / \mathrm{mol}- \\
\text { kelvin }\end{array}$ & $\begin{array}{c}\Delta \mathrm{S} \\
\mathrm{Cal} / \mathrm{mol}- \\
\text { kelvin }\end{array}$ & $\begin{array}{c}\Delta \mathrm{H} \\
\mathrm{Cal} / \mathrm{mol}- \\
\text { kelvin }\end{array}$ & $\begin{array}{c}\Delta \mathrm{G} \\
\mathrm{Kcal} / \mathrm{mol}\end{array}$ \\
\hline Adenosine & 4.427 & 0.603 & -0.02 & 114.3322 & 120.0362 \\
\hline Guanosine $\mathrm{n}$ & 4.301 & -6.44 & 0.01 & 108.4612 & 105.0077 \\
\hline Cytidine monophosphate & 4.197 & -3.059 & 0.0032 & 148.9707 & 149.5355 \\
\hline Thymidine monophosphate & 3.874 & -2.392 & 0.0033 & 145.7077 & 144.9684 \\
\hline
\end{tabular}

Table 7: Difference of Thermodynamic Functions of single-stranded DNA and their oxide form

\begin{tabular}{lccccc}
\hline structure & $\begin{array}{c}\Delta \mathrm{E} \\
\mathrm{Kcal} / \mathrm{mol}\end{array}$ & $\begin{array}{c}\Delta \mathrm{CV} \\
\mathrm{Cal} / \mathrm{mol}- \\
\text { kelvin }\end{array}$ & $\begin{array}{c}\Delta \mathrm{S} \\
\mathrm{Cal} / \mathrm{mol}- \\
\text { kelvin }\end{array}$ & $\begin{array}{c}\Delta \mathrm{H} \\
\mathrm{Cal} / \mathrm{mol}- \\
\mathrm{kelvin}\end{array}$ & $\begin{array}{c}\Delta \mathrm{G} \\
\mathrm{Kcal} / \mathrm{mol}\end{array}$ \\
\hline Single-strand AA & -4.743 & -7.867 & -0.37 & 362.1984 & 298.0670 \\
Single-strand GG & -8.382 & -12.386 & 0.21 & 348.3305 & 359.5001 \\
Single-strand CC & -14.708 & -16.225 & -0.36 & 356.1743 & 367.4068 \\
Single-strand TT & -16.548 & -23.659 & -0.06 & 379.5804 & 397.4645 \\
Single-strand GC & -7.797 & -9.83 & -0.05 & 383.5338 & 399.1473 \\
Single-strand AT & -5.095 & -7.244 & -0.013 & 361.8847 & 365.8562 \\
\hline
\end{tabular}


REVISTA DE LA UNIVERSIDAD DEL ZULIA. 3a época. Año $11 \mathrm{~N}^{\circ}$ 29, 2020

Mehdi Imanzadeh et al./// Theoretical methods for measuring chemo-physical... 428-446

3.8. Comparing the results of this study with similar research methods

A comparision table 8 between the results of this study and other research methods is presented.

Table 8: compares the results of this study with other research methods.

\begin{tabular}{|c|c|c|c|}
\hline Research group & Type of review & $\begin{array}{c}\text { Research } \\
\text { Methodology }\end{array}$ & Results \\
\hline Forster\& et al., 2018 & $\begin{array}{l}\text { Influence of oxygen } \\
\text { on DNA Degradation }\end{array}$ & Monte Carlo & $\begin{array}{l}59 / 5 \% \text { of Degradation in } \\
19 \% \mathrm{eV}\end{array}$ \\
\hline Baglion\&ret al., 2008 & $\begin{array}{l}\text { Examining the DNA } \\
\text { structure containing } \\
42 \text { bases }\end{array}$ & Monte Carlo & $\begin{array}{l}\text { Bottom } 6 \text {-sided structure } \\
\text { with a diameter of } 7 \mathrm{~nm}\end{array}$ \\
\hline Kino\& et al., 2012 & $\begin{array}{l}\text { Degradation and } \\
\text { oxidation of guanine }\end{array}$ & Gossin & $\begin{array}{l}\text { Sustainable Energy } 19 / 9 \\
\mathrm{kcal} / \mathrm{mol} \text { for Sp2:G } \\
16 / 3 \mathrm{kcal} / \mathrm{mol} \text { for Oz:G }\end{array}$ \\
\hline Current Research & $\begin{array}{l}\text { Investigation of } \\
\text { Physical and } \\
\text { Chemical Properties } \\
\text { Of nucleotides in } \\
\text { DNA mutation and } \\
\text { oxidation }\end{array}$ & Gossin & $\begin{array}{l}\text { GG sequence with } \\
\text { 0/45919 EGap in single- } \\
\text { stranded and sequence of } \\
\text { GC in double-stranded } \\
\text { with the most-likely } \\
\text { points of mutation and } \\
\text { oxidation. And by } \\
\text { examining the NMR } \\
\text { spectrum and the } \\
\text { spectrum differences in } \\
\text { the cases of normal and } \\
\text { abnormal, identified } \\
\text { cancer DNA. }\end{array}$ \\
\hline
\end{tabular}

2,2,4-Triamino-5(2H)-oxazolone: guanine

$\mathrm{Oz}: \mathrm{G}$

Sp2:G spiro-imino-dihydantoin: guanine

Conclusion

The results of the DFT calculations and Gaussian and NBO software have very high accuracy and the results from the calculations with this software have shown good agreement with experimental results. The computational method of QM / MM is superior to that of taking all the forces of gravity and physical, chemical and electron repulsion between atoms and their links between them, in comparison with other methods. Also it can be seen by examining the chemical displacement spectra and 
REVISTA DE LA UNIVERSIDAD DEL ZULIA. 3a época. Año $11 \mathrm{~N}^{\circ}$ 29, 2020

Mehdi Imanzadeh et al./// Theoretical methods for measuring chemo-physical... 428-446

anisotropy of the latency tensor in the Double-stranded DNA with GC sequence, the oxygen atom of the phosphate group in the guanosine nucleotide of the abnormal form has the highest value than the natural form and oxygen atoms belonging to the phosphate group in the cytotine nucleotide changed with less intense than guanine in these parameters. Also it can be seen by examining the spectra of Double-stranded DNA with AT sequence that the oxygen atom of the phosphate group in the abnormal form of the adenine nucleotide has the highest value than the natural form of DNA. Also the oxygen atom of the phosphate group in the thymidine nucleotide changed with less intense than adenine in these parameters.

\section{References}

Aghelan, Z., Panjehpour, M.(2016). The role of DNA polymerase in carcinogenicity (review article). Qom University of Medical Sciences Journal, 10(5), 101- 115.

Bandyopadhyay, N., Pradhan, A. B., Das, S., Lu, L., Zhu, M., Chowdhury, S., \&Naskar, J. P. (2016). Synthesis, structure, DFT calculations, electrochemistry, fluorescence, DNA binding and molecular docking aspects of a novel oxime based ligand and its palladium (II) complex. Journal of Photochemistry and Photobiology B: Biology, 160, 336-346.

Bensimon, A., Aebersold, R., \& Shiloh, Y. (2011). Beyond ATM: the protein kinase landscape of the DNA damage response. FEBS letters, 585(11), 1625-1639.

Facelli, J.C. (2002). Encyclopedia of Nuclear Magnetic Resonance; D. M. Grant, R. K. Harris, Eds., London: John Wiley \& Sons., 9, 323 (2002)

Forshew, T., Murtaza, M., Parkinson, C., Gale, D., Tsui, D. W., Kaper, F., ... \& Hadfield, J. (2012). Noninvasive identification and monitoring of cancer mutations by targeted deep sequencing of plasma DNA. Science translational medicine, 4(136), 136ra68136 ra68.

Gray, H. B. (2006). Charge transfer in DNA: from mechanism to application. John Wiley \& Sons.

Grozema, F. C., Tonzani, S., Berlin, Y. A., Schatz, G. C., Siebbeles, L. D., \& Ratner, M. A. (2008). Effect of structural dynamics on charge transfer in DNA hairpins. Journal of the American Chemical Society, 130(15), 5157-5166.

Hall, D. B., Holmlin, R. E., \& Barton, J. K. (1996). Oxidative DNA damage through longrange electron transfer. Nature, 382(6593), 731. 
REVISTA DE LA UNIVERSIDAD DEL ZULIA. 3a época. Año $11 \mathrm{~N}^{\circ}$ 29, 2020

Mehdi Imanzadeh et al./// Theoretical methods for measuring chemo-physical... 428-446

Holmlin, R. E., Dandliker, P. J., \& Barton, J. K. (1997). Charge transfer through the DNA base stack. AngewandteChemie International Edition in English, 36(24), 2714-2730.

Hume, P. A., Brimble, M. A., \& Reynisson, J. (2013). DNA adduct formation of mitomycin C. A test case for DFT calculations on model systems. Computational and Theoretical Chemistry, 1005, 9-15.

Lari, A., Haghkhah, M., Yazdani, M.(2016). Application of computational methods and molecular modeling in accessing new anticancer drugs.Zanko Journal of Medical Sciences / Kurdistan University of Medical Sciences

Mollaamin, F.; Monajjemi, M. (2015). Harmonic Linear Combination and Normal Mode Analysis of Semiconductor Nanotubes Vibrations. Journal of Computational and Theoretical Nanoscience. Vol. 12, 1030-1039, 2015

Prat, F., Houk, K. N., \& Foote, C. S. (1998). Effect of guanine stacking on the oxidation of 8-oxoguanine in B-DNA. Journal of the American Chemical Society, 120(4), 845-846.

Reed; A. E.; Curtiss, L. A.; Weinhold, F. (1988). Chem. Rev., 88, 899 (1988)

Steenken, S., \&Jovanovic, S. V. (1997). How easily oxidizable is DNA? One-electron reduction potentials of adenosine and guanosine radicals in aqueous solution. Journal of the american chemical society, 119(3), 617-618.

Study on interaction between carbon nanotubes (CNTs) as nano carrier for loading and delivery of Methotrexate, Int. J. Bio-Inorg. Hybr. Nanomater., 7(2): 145-162 Summer 2018

Sun, Q., Li, F., Sun, F., \& Niu, J. (2015). Interleukin-8 is a prognostic indicator in human hilar cholangiocarcinoma. International journal of clinical and experimental pathology, 8(7), 8376.

Yan, H., Yuan, W., Velculescu, V. E., Vogelstein, B., \& Kinzler, K. W. (2002). Allelic variation in human gene expression. Science, 297(5584), 1143-1143.

Zhai, Y. F., Wirth, J. J., Welsch, C. W., \&Esselman, W. J. (2012). 6. Protein tyrosine phosphatases: Cellular regulators of human breast cancer. Mammary Tumor Cell Cycle, Differentiation, and Metastasis: Advances in Cellular and Molecular Biology of Breast Cancer, 83, 107. 